\title{
The Influence of REACT learning strategies on mathematics learning outcomes and learning activities of fifth grade students at SDN Lariangbangi Makassar
}

\author{
Latri Aras ${ }^{1)}$, Agusalim Juhari ${ }^{2}$ \\ ${ }^{1}$ Prodi Pendidikan Guru Sekolah Dasar FIP UNM \\ ${ }^{2}$ STKIP Pembangunan Indonesia \\ e-mail: ${ }^{1}$ unmlatri2014@gmail.com ${ }^{2}$ agusalimjuhari@gmail.com
}

\begin{abstract}
The results showed that: (1) The average feasibility of learning Mathematics taught using the REACT Learning Strategy was 3.60 out of an ideal score of 4 being in the well-implemented category, (2) The average score of student activity during Mathematics learning being taught by using the REACT Learning Strategy class V SDN Lariangbangi II Makassar is 3.10 out of an ideal score of 4 being in the active category, (3) (a) The average learning outcomes of students taught using the REACT strategy of 86.04 from the Ideal Score 100 and standard deviation 6.05. Descriptively the learning outcomes of students taught with the REACT learning strategy are higher than the KKM value of 78. (b) The average increase in learning outcomes of students taught using the REACT strategy is 0.80 and the standard deviation is 0.09. Descriptively, the increase in learning outcomes of students taught with the REACT strategy is higher than the moderate gain value of 0.3 , and (4) (a) There is a significant effect on the REACT Learning Strategy on Mathematics learning outcomes in SDN Class 5 Lariangbangi State Elementary School. (b) Learner activities with the implementation of the REACT strategy which are observed to be overall active in the process of learning activities.
\end{abstract}

Keywords: REACT Learning Strategy, Mathematics Learning Outcomes, Learning Activity.

\section{INTRODUCTION}

National Education System Law No. 20 of 2003 states learning is a process of interaction of students with educators and learning resources in a learning environment. Learning as a learning process built by teachers to develop thinking creativity that can develop students' thinking abilities, and can improve the ability to construct new knowledge in an effort to increase good mastery of the subject matter.

Mathematics lessons are the foundation and framework of science and technology. According Kusumaningtyas (2016: 1) mathematics is a basic science that continues to experience growth both in terms of theory and aspects of its application. As a basic science, mathematics is widely used in all fields of human life, so we need an effort in learning mathematics to be carried out optimally. The teacher as a subject who teaches Mathematics should be able to arrange various appropriate learning programs such as learning strategies that are in accordance with the learning objectives to be achieved.

Related to this, information obtained from the results of the mathematics teacher interviews at SDN Lariangbangi I, II, and III Makassar stated that the lack of absorption and attention in the Mathematics learning process resulted in students in doing assignments often having difficulty doing it correctly. Teachers sometimes complain because some students are indifferent to the lessons given 
and only students who have a high level of understanding are able to receive lessons well, while other students only follow the teacher's direction. The impact of student learning outcomes is not as expected, namely not achieving KKM (minimum completeness criteria).

Implementing a variety of learning strategies in the classroom, theoretically more hope for the success of students in the learning process, where various strategies can be used in the learning process. According Purwosusilo (2014) REACT learning strategies contain 5 (five) strategies that can anticipate problems such as the lack of student attention in learning. The five REACT strategies are relating, experiencing, applying, cooperating and transferring (Relating, Experiencing, Applying, Cooperating, Transfering). REACT learning strategy is one form of alternative learning that requires active involvement of students.

Based on the background stated above, the formulation of the problem in this study are:

1. How is the implementation of Mathematics Learning taught by the REACT Learning strategy in Lariangbangi Elementary School Students?

2. How are the Mathematics Learning Activities for Class 5 Students at Lariangbangi Elementary School being taught using the REACT Learning Strategy?

3. How are the Mathematics Learning Results of Class 5 students at SDN Lariangbangi taught using the REACT Learning Strategy?

4. Is there a significant influence on REACT Learning Strategies on Mathematics Learning Outcomes and Student Activities in SDN Class 5 Lariangbangi Elementary School?

\section{RESEARCH METHODS}

This research is an experimental research. Because there is treatment, the research approach used is a quantitative approach with a pre-experimental design. This research was carried out in a group that was initiated by giving pretest before and posttest after the treatment was carried out. The research design scheme is as follows.

Table 1 Research Design

\begin{tabular}{cccc}
\hline Kelompok & Pre-test & Treatment & Post-test \\
\hline Eksperimen & $\mathrm{O}_{1}$ & $\mathrm{~T}_{1}$ & $\mathrm{O}_{2}$ \\
\hline
\end{tabular}

Sumber: Sugiyono (2015)

The population in this study were all students of class V SDN Lariangbangi Makassar in the Genao semester of 2018/2019 academic year consisting of 3 schools in it, SDN Lariangbagi I, SDN Lariangbagi II, and SDN Lariangbagi III, each consisting of 1 class 5 The sample selection technique used in this study is the "Simple random sampling" technique with the selected sample is Class V SDN Lariangbangi II with 24 students. 
There are two types of variables used in this study, namely the independent variable and the dependent variable. The independent variable in this study is the REACT learning strategy and the dependent variable in this study is the results of mathematics learning and student learning activities.

The procedure used in this study was divided into three stages: the preparation phase, the implementation phase and the final stage. The preparatory phase carried out is preparing learning tools, data collection instruments, preparing teachers and observers. Then the implementation phase is giving a preliminary test (pretest) to determine the initial ability of students, the implementation of learning in class VIII by applying Inquiry and REACT learning strategies with a frequency of 5 meetings according to the RPP, filling out the observation sheet during the learning process and giving the final test ( posttest) to find out the learning outcomes of students after applying the REACT learning strategy. Furthermore, the activities carried out at the final stage are processing data from research results, analyzing and discussing research data and concluding research results.

The learning tools used consist of: (1) Learning implementation plan, (2) Student activity sheet while the research instruments used consist of: (1) Learning implementation observation sheet, (2) Student activity observation sheet, (3) Test learning outcomes. The research tools and instruments have been validated by two expert validators and declared valid to be applied in the learning process.

The data collection methods used in this study are as follows:

1. Learning performance data is obtained from the results of the learning implementation observation sheet that is filled out by the observer during the learning process.

2. Data regarding activities in teaching and learning activities are obtained from the observation sheet of students' mathematical activities.

3. Data regarding the mathematics learning outcomes of students, obtained from the results of tests conducted on the pretest and posttest using different scoring guidelines rubrics.

\section{Descriptive Statistical Analysis}

Descriptive statistical analysis is used to analyze data on the performance of learning, student activities during learning, and student learning outcomes.

a. Description of the implementation of REACT learning strategy learning Data analysis techniques for the implementation of learning based on the planned implementation of the Inq REACT learning strategy used an average analysis, meaning that the teacher's ability level is calculated by adding up the value of each aspect then dividing it by the number of aspects assessed. As for determining the category of aspects of the implementation of learning strategies based on the criteria, namely (1) Not done well, (2) Not implemented, (3) Enough implemented, (4) Well implemented. The criterion for implementation of a learning strategy is achieved if it is in the wellimplemented category.

b. Description of student activities 
Data observations of students' activities during the learning activities take place were analyzed using percentages. The percentage of observations of student activity that is the frequency of each aspect of observation divided by the aspect of observation $100 \%$ times. The determination of the category of aspects of student activity based on criteria is very inactive, inactive, quite active, active and very active.

c. Description of learning outcomes in mathematics

The data analyzed in this study are the values of the results of the pretest and posttest by looking at the increase in scores before and after the application of the REACT learning strategy. Gain shows an increase in students' mathematics learning outcomes after the learning is done by the teacher. This is done to avoid the results of biased research conclusions. The advantages of using learning to improve student learning outcomes are reviewed based on comparison of normalized gain values, which can be calculated by equations (Sundayana, 2014: 154):

$$
g=\frac{\text { skor posttest }- \text { skor pretest }}{\text { skor }(\text { ideal })-\text { skor pretest }}
$$

Data analysis techniques with inferential statistics are used for the purposes of testing research hypotheses. Because the hypothesis being tested is the similarity of two averages, an independent sample t-test analysis is used. The data inferential analysis are learning outcome data, and learning achievement improvement data after inquiry and REACT learning strategies in mathematics learning. The statistical analysis used is:

Test for normality

Normality test is used to find out whether data is normally distributed or not. In this study the Shapiro-Wilk test was used using a significance level of $\alpha=5 \%$ or 0.05 . With criteria:

If $\boldsymbol{\rho}$ value $\geq 0.05$ then the data comes from populations that are normally distributed If $\boldsymbol{\rho}$ value $<0.05$ then the data comes from populations that are not normally distributed

Hypothesis test

To test the hypothesis used t test with a significance level $\alpha=0.05$. The type of $t-$ test used is one sample t-test. The data analyzed using the t-test are data of learning outcomes, and an increase in the value of student learning outcomes. This test is carried out to test the research hypotheses about learning outcomes on the $\mathrm{KKM}$ value (78) and data on the increase in learning outcomes on the minimum gain value of being (0.30) taught by the REACT learning strategy in mathematics learning. The testing criteria are:

Ho is accepted if $\boldsymbol{\rho}$ value $\geq 0.05$

Ho is rejected if $\boldsymbol{\rho}$ value $<0.05$ 


\section{RESULTS AND DISCUSSION}

1. Descriptive Analysis Results

a. Implementation of Learning

The results of observations of the implementation of the REACT learning strategy in class V SDN Lariangbangi II Makassar in learning mathematics, namely, the average of learning achievement was 3.60 out of an ideal score of 4 being in the well-implemented category.

b. Student activities

Student activities that are converted based on the rubric of assessment and recapitulation of learners' activities based on the category of activity aspects namely, for the average activity score of fifth grade students of SD Lariangbangi II Makassar is 3.10 which is in the active category so that it can be concluded that the activities of students in the process learning with the implementation of the REACT strategy which is observed as being entirely active in the process of learning activities.

c. Student Learning Outcomes

Descriptive analysis of the scores of students 'learning outcomes in class V SDN Lariangbangi II Makassar can be seen that is, based on the average score of students' mathematics learning outcomes in the pre-test of 26.75 with a standard deviation of 7.96 from an ideal score of 100 is in the very low category. The highest value was 40 and the lowest value was 15 . While in the post-test it was stated that the average score of students' mathematics learning outcomes was 86.04 with a standard deviation of 6.05 from the ideal score of 100 being in the high category. The highest score is 100 and the lowest score is 75 . If the learning outcomes are grouped into 5 categories, the frequency distribution and percentage are obtained, namely for the pre-test there are 24 students who get a score of very low learning outcomes in the Material Collection and Presentation of Data before applying the strategy REACT learning. This means that the learning outcomes of students in the Data Collection and Presentation material are still very low. Whereas for the post-test it can be seen that from the 24 students who became the study sample there were 3 students who obtained the learning outcomes score in the medium category, 15 students obtained the learning outcomes score in the high category, and 6 students obtained the learning outcomes score in the very high category in the Data Collection and Presentation material after applying the REACT learning strategy. This means that the ability of students in the Data Collection and Presentation material is in the high category with an average score of 86.04. Thus it can be concluded that the learning outcomes of students with REACT learning strategies in class V SDN Lariangbangi II Makassar can improve student learning outcomes from before.

If seen in the improvement of students' learning outcomes from pre-test to post-test scores with the application of the REACT strategy in class V students of SDN Lariangbangi II Makassar, the average score of improvement in mathematics learning outcomes of students taught with the REACT learning strategy is an average of 0.80 with a standard deviation of 0.09 out of an ideal score of 1 being in the high category. The highest value is 1 and the lowest value is 0.61 . If an 
increase in student learning outcomes is grouped into 3 categories, the frequency distribution and percentage are obtained as follows:

Table 2 Frequency Distribution and Percentage Improvement of Student Learning Outcomes Score REACT Strategy in class V SDN Lariangbangi II Makassar

\begin{tabular}{cccr}
\hline Skor & Category & Frekuency & Persentase(\%) \\
\hline $0,00<\mathrm{g}<0,30$ & Low Increase & 0 & 0,0 \\
$0,30 \leq \mathrm{g}<0,70$ & Medium Increase & 3 & 12,5 \\
$0,70 \leq \mathrm{g} \leq 1,00$ & High Increase & 21 & 87,5 \\
\hline
\end{tabular}

2. Results of inferential analysis

Normality test

Normality test results after REACT Strategy Learning obtained data that the learning outcomes of students in the inquiry strategy in class V SDN Lariangbangi II Makassar obtained $p$-value $=0.507$ for the Shapiro-Wilk normality test. The $\mathrm{p}$ value is greater than $\alpha=0.05$ so it can be concluded that the learning outcomes of V students of SD Lariangbangi II Makassar are normally distributed.

Improved student learning outcomes for the REACT Strategy in V SDN Lariangbangi II Makassar obtained p-value $=0.411$ for Shapiro-Wilk normality test. The p-value is greater than $\alpha=0.05$ so that it can be concluded that the data about the increase in student outcomes in class V SDN Lariangbangi II Makassar are distributed.

Hypothesis testing

Based on the results of the analysis it appears that the average learning outcomes of students taught using the REACT strategy of 86.04 and 6.05 standard deviations. This means descriptively the learning outcomes of students taught with the REACT learning strategy are higher than the KKM value of 78 . While based on the results of the One Samples t-Test output obtained by numbers

$$
\text { sig. (2 tailed) atau } p-\text { value }=\frac{0,000}{2}=0<0,05 \text {, atau } H_{0}
$$

is rejected.

Thus, the hypothesis proposed was tested by the data, so it was concluded that the Mateamtika learning outcomes taught by the REACT learning strategy were higher than the KKM score of 78

Improved learning outcomes based on the analysis result shows that the average increase in learning outcomes of students taught using the REACT strategy is 0.80 and the standard deviation is 0.09 . This means descriptively the increase in 
learning outcomes of students taught with the REACT strategy is higher than the moderate gain value of 0.3. While based on the results of the One Samples t-Test output obtained by numbers sig. (2 tailed) atau $p-$ value $=\frac{0,000}{2}=0<$ 0,05 , atau $H_{0}$ is rejected. Thus, the hypothesis proposed is tested by the data, so it can be concluded that the Mateamtika learning outcomes taught by the REACT learning strategy are higher than the moderate Gain value of 0.3

Based on the results of descriptive and inferential analysis, it can be concluded (a) that there is a significant effect of REACT Learning Strategies on Mathematics learning outcomes in SDN Class 5 Lariangbangi Elementary School, (b) Student activities by applying the REACT strategy which is observed as a whole is active in the learning process .

This is consistent with the results of research which states that mathematics learning outcomes can be improved by applying the REACT Learning Strategy (Fauziah, 2010; Marthen, 2010; Kusumawati, et al, 2010). As according to Arifin, et al (2014), Effective REACT Learning Strategies in Mathematics learning

\section{CONCLUSIONS AND SUGGESTIONS Conclusions}

Based on the results of research and discussion, the conclusions in this study are as follows:

1. The average feasibility of learning mathematics taught using the REACT Learning Strategy is 3.60 of the ideal score of 4 being in the wellimplemented category.

2. The average score of student activity during Mathematics learning taught by using the REACT Learning Strategy for class V SDN Lariangbangi II Makassar is 3.10 out of an ideal score of 4 being in the active category

3. (a)The average learning outcomes of students taught using the REACT strategy of 86.04 from an Ideal Score of 100 and a standard deviation of 6.05. Descriptively the learning outcomes of students taught with the REACT learning strategy are higher than the KKM value of 78. (b) The average increase in learning outcomes of students taught using the REACT strategy is 0.80 and the standard deviation is 0.09 . Descriptively, the increase in learning outcomes of students taught with the REACT strategy is higher than the moderate gain value of 0.3

4. (a)There is a significant effect of REACT Learning Strategies on Mathematics Learning Outcomes at SDN Class 5 Lariangbangi Elementary School. (b) Learner activities with the implementation of the REACT strategy which are observed to be overall active in the learning activity process

\section{REFERENCES}

Arifin, A. T., Kartono, K., \& Sutarto, H. (2014). Keefektifan Strategi Pembelajaran React Pada Kemampuan Siswa Kelas VII Aspek Komunikasi Matematis. Kreano, Jurnal Matematika Kreatif-Inovatif, 5(1), 91-98. Departemen Pendidikan Nasional. (2005). Rencana Strategis 
Departemen Pendidikan Nasional 2005-2009. Jakarta: Pusat Informasi dan Humas Depdiknas.

Fauziah, A. (2010, June). Peningkatan kemampuan pemahaman dan pemecahan masalah matematik siswa SMP melalui strategi REACT. In Forum kependidikan (Vol. 30, No. 1, pp. 1-13).

Kusumaningtyas, W. (2016). Efektivitas Metode Inquiry Terhadap Hasil Belajar Matematika Siswa. JURNAL E-DuMath, 2(1).

Kusumawati, E., \& Rizki, N. D. (2014). Pembelajaran Matematika Melalui Strategi REACT Untuk Meningkatkan Kemampuan Pemecahan Masalah Matematis Siswa SMK. EDU-MAT: Jurnal Pendidikan Matematika, 2(2). Marthen, T. (2010). Pembelajaran melalui pendekatan REACT meningkatkan kemampuan matematis siswa SMP. Jurnal Penelitian Pendidikan, 11(2), 11-20.

Purwosusilo. (2014). Peningkatan kemampuan pemahaman dan Pemecahan Masalah Matematika Siswa SMk Melalui Strategi Pembelajaran React di SMK Negeri 52 Jakarta. Jurnal Kependidikan Dan Keguruan, 1(2).

Sagala, S. (2011). Konsep dan Makna Pembelajaran. Bandung: Alfabeta. Sundayana, R. (2014). StatistikaPenelitianPendidikan. Bandung: Alfabeta Sugiyono. (2015). Cara Mudah Menyusun Tesis dan Disertasi. Bandung: Alfabeta. 